\title{
MOTIVASI BELAJAR SISWA SMK NEGERI 1 CIREBON PADA PEMBELAJARAN MATEMATIKA
}

\author{
Devy Liyana ${ }^{1}$, Neneng Aminah ${ }^{2}$, Dadang Rohimati ${ }^{3}$, Dwiniasih ${ }^{4}$ \\ Universitas Swadaya Gunung Jati ${ }^{1,2,3,4}$ \\ devyliyana98@gmail.com
}

\begin{abstract}
Abstrak
Penelitian ini bertujuan untuk mengetahui sejauh mana motivasi belajar siswa pada pembelajaran matematika. Penelitian ini dilakukan pada siswa SMK Negeri 1 Cirebon kelas XI TPM 1 sebanyak 26 orang sebagai sampel. Metode penelitian yang digunakan adalah metode ex-post facto, pengambilan data dilakukan melalui pengisian angket atau kuesioner motivasi belajar dan teknik analisis data yang digunakan dalam penelitian ini adalah teknik kuantitatif statistika deskriptif. Hasil penelitian ini secara keseluruhan menunjukkan bahwa motivasi belajar siswa pada pembelajaran matematika SMK Negeri 1 Cirebon kelas XI TPM 1 sebesar 58\% termasuk dalam kategori sedang. Hal ini menunjukkan bahwa motivasi belajar sangat berpengaruh dalam pembelajaran matematika.
\end{abstract}

Kata Kunci: Motivasi Belajar, Pembelajaran Matematika, Metode Ex-Post Facto

\begin{abstract}
This study aims to determine the extent of student motivation in learning mathematics. This research was conducted on 26 student of SMK Negeri 1 Cirebon class XI TPM 1 as many as a sample. The research method used is the ex-post facto method, the data collection was carried out through questionnaires or learning motivation questionnaires and the data analysis technique used in this study was a descriptive quantitative statistical technique. The result of this study as a whole show that student motivation in learning mathematics at SMK Negeri 1 Cirebon class XI TPM 1 is 58\% include in the medium category. This show that learning motivation is very influential in learning mathematics.
\end{abstract}

Keywords: Learning Motivation, Mathematics Learning, Ex-Post Facto Method

\section{PENDAHULUAN}

Pembelajaran merupakan ujung tombak dalam proses pendidikan disekolah, sehingga pembelajaran yang berlangsung dalam rangka mencapai tujuan kompetensi lulusan bukan hanya berlangsung untuk mentransfer ilmu pengetahuan dari guru ke siswa saja tetapi bagaimana siswa juga terlibat aktif pada proses pembelajaran. Aktifnya siswa dalam pembelajaran dapat membantunya menemukan, mengembangkan, memecahkan masalah, dan mengkomunikasikan ide-ide yang dia miliki sekaligus bisa memupuk minat dan sikap positif serta menumbuhkan motivasi tinggi saat pembelajaran berlangsung. Hal ini sesuai dengan standart proses pembelajaran yang telah diatur dalam Peraturan Menteri Pendidikan Nasional Nomor 41 tahun 2007, disebutkan bahwa proses pembelajaran pada satuan pendidikan diselenggarakan secara interaktif, inspiratif, menyenangkan, menantang, memotivasi peserta didik untuk berpartisipasi aktif, serta memberikan ruang yang cukup bagi prakarsa, kreativitas, dan kemandirian sesuai dengan bakat, minat, dan perkembangan fisik serta psikologi peserta didik. 
Bagi dunia keilmuan, matematika merupakan bahasa simbolik yang memungkinkan terjadinya komunikasi yang cermat dan tepat. Pembelajaran juga harus dapat menumbuhkan motivasi belajar dan sikap siswa terhadap matematika. Motivasi merupakan factor penggerak maupun dorongan yang dapat memicu timbulnya rasa semangat dan juga mampu merubah tingkah laku manusia atau individu untuk menuju pada hal yang lebih baik untuk dirinya sendiri. Motivasi belajar memegang peranan penting dalam proses pembelajaran matematika. Motivasi belajar siswa dapat ditingkatkan dengan menerapkan model atau strategi pembelajaran yang melibatkan siswa aktif dalam pembelajaran.

Dengan adanya motivasi diharapkan siswa akan lebih giat dalam belajar dan mampu meraih prestasi yang diharapkan. Menurut Schunk (Terjemahan 2014) "teori motivasi berprestasi berpengaruh bagi pengajaran dan pembelajaran". Schunk et al (2014) juga menambahkan "Motivation is the process whereby goaldirected activity is instigated and sustained". Pernyataan tersebut bermakna motivasi adalah proses dimana kegiatan tujuan diarahkan untuk menghasut/mendorong dan mendukung. Pengalaman dan pengamatan peneliti di SMK Negeri 1 Cirebon kelas XI TPM 1 pada mata pelajaran matematika, motivasi siswa dalam mengikuti proses pembelajaran masih sangat rendah. Hal tersebut dapat dilihat dari aktifitas siswa dalam mengikuti proses pembelajaran antara lain : tidak memperhatikan guru saat menjelaskan, keluar masuk kelas, mengganggu teman sebangku, mengobrol dengan teman lainya, mengantuk, bermain ponsel dan sebagainya.

Hal ini diperkuat oleh Penelitian Kamaluddin [2] menunjukan bahwa pertama, motivasi belajar memiliki pengaruh positif terhadap prestasi belajar matematika siswa. Siswa dengan tingkat motivasi yang baik memiliki kecenderungan lebih besar untuk mencapai prestasi maksimal. Kedua, tingkat motivasi belajar siswa dipengaruhi oleh beberapa unsur utama, yaitu individu siswa, guru, konten pembelajaran, metode dan sumber belajar yang digunakan, serta lingkungan belajar siswa. Guru sebagai fasilitator dalam proses pembelajaran memiliki peran penting untuk dapat mengoptimalkan unsur-unsur tersebut. Ketiga, untuk meningkatkan motivasi belajar siswa, guru sebagai fasilitator dalam proses pembelajaran di kelas.

\section{METODE}

Penelitian ini menggunakan metode penelitian ex-post facto. Populasi yang digunakan dalam penelitian ini adalah siswa SMK Negeri 1 Cirebon dan sampel yang digunakan dalam penelitian ini adalah siswa kelas XI TPM 1 berjumlah 26 siswa. Teknik pengumpulan data merupakan cara-cara yang dilakukan untuk memperoleh data dan keterangan-keterangan yang diperlukan dalam penelitian. Dalam penelitian ini teknik pengumpulan data menggunakan angket motivasi belajar dan instrumen yang digunakan untuk mengumpulkan data yaitu dengan mengunakan angket.

Teknik analisis data yang digunakan dalam penelitian ini adalah teknik kuantitatif statistika deskriptif. Statistik deskriptif adalah statistik yang digunakan untuk menganalisis data dengan cara mendeskripsikan atau menggambarkan data yang telah terkumpul sebagaimana adanya tanpa bermaksud membuat kesimpulan yang berlaku untuk umum atau generalisasi. Statistik deskriptif dapat digunakan bila 
peneliti hanya ingin mendeskripsikan data sampel, dan tidak ingin membuat kesimpulan yang berlaku untuk populasi dimana sampel diambil.

\section{HASIL DAN PEMBAHASAN}

Berdasarkan data yang telah diperoleh dari lapangan, agar mudah dipahami maka dideskripsikan ke dalam berbagai bentuk penyajian. Penyajian data pada penelitian ini dengan menggunakan tabel. Data hasil penelitian motivasi belajar matematika siswa SMKN 1 Cirebon secara keseluruhan disajikan dalam bentuk sebagai berikut :

TABEL 1. Rekapitulasi Angket Motivasi Belajar

\begin{tabular}{ccc}
\hline Pernyataan & Rata-Rata & Presentase \\
\hline 1 & 22 & $85 \%$ \\
\hline 2 & 19 & $73 \%$ \\
\hline 3 & 20 & $77 \%$ \\
\hline 5 & 20 & $77 \%$ \\
\hline 6 & 11 & $42 \%$ \\
\hline 7 & 19 & $73 \%$ \\
\hline 8 & 5 & $19 \%$ \\
\hline 9 & 3 & $12 \%$ \\
\hline 10 & 13 & $50 \%$ \\
\hline Rata-Rata Keseluruhan & 20 & $77 \%$ \\
\hline
\end{tabular}

Berdasarkan Tabel 1 di atas, menunjukkan bahwa pernyataan pertama memiliki persentase sebesar $85 \%$ dan pernyataan tersebut termasuk dalam kategori tinggi. Dari 26 siswa yang diminta untuk mengisi angket terdapat 22 siswa yang menjawab YA, hal tersebut memiliki arti bahwa hampir seluruh siswa dikelas tersebut merasa bahwa pelajaran matematika adalah pelajaran yang sulit. Pada dasarnya, siswa yang mengenyam pendidikan di jenjang SMK cenderung tidak terlalu menyukai pelajaran eksak seperti matematika, karena dalam system pendidikan di SMK pembagian jadwal antara praktikum sesuai jurusan dengan pelajaran umum seperti matematika kurang seimbang. Di SMKN 1 Cirebon sendiri untuk matematika hanya terdapat 4 jam pelajaran dalam satu minggu. Tentu hal ini berdampak pada keterbiasaan siswa untuk mempelajari matematika semakin berkurang. Hal inilah menjadi salah satu penyebab mengapa siswa berpikir bahwa matematika adalah pelajaran yang sulit.

Pada pernyataan kedua memiliki persentase sebesar $73 \%$ dan pernyataan tersebut termasuk dalam kategori tinggi. Dari 26 siswa yang diminta mengisi angket terdapat 19 siswa yang menjawab YA. Hal ini berarti hampir setengah dari jumlah siswa dikelas tersebut memiliki harapan untuk pembelajaran matematika dibuat dengan semenyenangkan mungkin agar tidak terasa terlalu memberatkan siswa. Pada saat observasi, penulis mencoba menggunaan teknologi berupa aplikasi Ispring yang berguna pada saat siswa menjawab soal yang diberikan. Hasilnya siswa sangat aktif dan bersamangat untuk menyelesaikan soal dan menjawab nya 
dengan aplikasi Ispring yang diberikan. Pada saat observasi juga penulis mencoba menggunakan model pembelajaran Numbered Head Together, model NHT ini adalah sesuatu yang baru bagi para siswa karena mereka terbiasa belajar dengan menggunakan pembelajaran yang konvesional. Hasilnya para siswa sangat antusias dengan model NHT tersebut dan siswa mengerjakan soal yang diberikan dengan bersungguh sungguh. Hal ini memiliki arti bahwa siswa menginginkan proses pembelajaran dibuat dengan menyenangkan dan baru bagi siswa.

Pada pernyataan ketiga memiliki persentase sebesar $77 \%$ dan pernyataan tersebut termasuk dalam kategori tinggi. Dari 26 siswa yang diminta untuk mengisi angket terdapat 20 siswa yang menjawab YA. Hal tersebut menunjukkan banyaknya siswa yang berpendapat bahwa siswa semangat belajar matematika karena matematika merupakan salah satu faktor terpenting bagi siswa untuk masuk perguruan tinggi dan dunia kerja kelak.

Pada pernyataan keempat memiliki persentase sebesar $77 \%$ dan pernyataan tersebut termasuk dalam kategori tinggi. Dari 26 siswa yang diminta untuk mengisi angket terdapat 20 siswa yang menjawab YA. Hal tersebut menunjukkan banyaknya siswa yang berpendapat bahwa siswa dapat mengatasi kesulitan saat belajar matematika dengan bertanya atau berdiskusi dengan guru atau teman.

Pada pernyataan kelima memiliki persentase sebesar $42 \%$ dan pernyataan tersebut termasuk dalam kategori sedang. Dari 26 siswa yang diminta untuk mengisi angket terdapat 11 siswa yang menjawab YA. Hal tersebut menunjukkan banyaknya siswa yang berpendapat bahwa suasana belajar matematika yang biasa dialami itu menyenangkan. Artinya lebih banyak siswa yang berpendapat bahwa suasana belajar matematika yang biasa dialami itu tidak menyenangkan.

Pada pernyataan keenam memiliki persentase sebesar $73 \%$ dan pernyataan tersebut termasuk dalam kategori tinggi. Dari 26 siswa yang diminta untuk mengisi angket terdapat 19 siswa yang menjawab YA. Hal tersebut menunjukkan sebagian siswa yang berpendapat bahwa dengan menguasai materi pada pelajaran matematika membuat siswa merasa lebih mudah menguasai mata pelajaran eksak lain seperti fisika, kimia dan pelajaran eksak lainnya.

Pada pernyataan ketujuh memiliki persentase sebesar $19 \%$ dan pernyataan tersebut termasuk dalam kategori rendah. Dari 26 siswa yang diminta untuk mengisi angket terdapat 5 siswa yang menjawab YA. Hal tersebut menunjukkan sebagian siswa yang berpendapat bahwa mereka menyukai mengerjakan atau menyelesaikan soal-soal matematika. Artinya terdapat 21 siswa yang berpendapat bahwa mereka tidak menyukai mengerjakan soal-soal matematika.

Pada pernyataan kedelapan memiliki persentase sebesar $12 \%$ dan pernyataan tersebut termasuk dalam kategori rendah. Dari 26 siswa yang diminta untuk mengisi angket terdapat 3 siswa yang menjawab YA. Hal tersebut menunjukkan beberapa siswa yang berpendapat bahwa jika mereka menjadi seorang guru, maka mereka akan memilih menjadi guru mata pelajaran matematika. Pernyataan kedelapan memiliki kategori paling rendah, karena orientasi siswa SMK setelah lulus adalah bekerja sesuai jurusan ataupun jika para siswa memiliki kesempatan untuk melanjutkan pendidikan menjadi seorang guru siswa tersebut lebih memilih jurusan yang sesuai pada saat siswa di SMK.

Pada pernyataan kesembilan memiliki persentase sebesar $50 \%$ dan pernyataan tersebut termasuk dalam kategori tinggi. Dari 26 siswa yang diminta 
untuk mengisi angket terdapat 13 siswa yang menjawab YA. Hal tersebut menunjukkan banyaknya siswa yang berpendapat bahwa mereka senang membagikan ilmu yang mereka kuasai khususnya yang berkaitan dengan matematika dengan cara berdiskusi.

Pada pernyataan kesepuluh memiliki persentase sebesar $77 \%$ dan pernyataan tersebut termasuk dalam kategori tinggi. Dari 26 siswa yang diminta untuk mengisi angket terdapat 20 siswa yang menjawab YA. Hal tersebut menunjukkan banyaknya siswa yang berpendapat bahwa mereka senang mencari solusi atas masalah khususnya yang berkaitan dengan pelajaran matematika.

Dari seluruh penyataan diatas didapat persentase sebesar $58 \%$, hal ini menunjukkan bahwa motivasi belajar siswa SMK Negeri 1 Cirebon dalam pembelajaran matematika termasuk dalam kategori sedang.

\section{KESIMPULAN}

Berdasarkan analisis dan pembahasan, maka dapat disimpulkan bahwa motivasi belajar siswa SMK Negeri 1 Cirebon dalam pembelajaran matematika sebesar 58\% termasuk dalam kategori sedang. Hal tersebut diketahui dari hasil persentase setiap pernyataan yang menunjukkan adanya keberagaman jawaban. Artinya siswa memiliki motivasi belajar dalam pembelajaran matematika yang dapat ditingkatkan lagi dengan cara dalam proses pembelajaran lebih dibuat menyenangkan dan baru bagi siswa.

\section{DAFTAR RUJUKAN}

[1] Jatmiko. 2015. Hubungan Motivasi Belajar dengan Hasil Belajar Matematika Siswa Kelas X SMK Nahdhatul Ulama Pace Nganjuk. Jurnal Math Educator Nusantara Volume 01 Nomor 02

[2] Kamaluddin. 2017. Pengaruh Motivasi Belajar Terhadap Prestasi Belajar Matematika dan Strategi untuk Meningkatkannya. Seminar Matematika dan Pendidikan Matematika UNY

[3] Oktava. 2018. Motivasi Belajar Matematika Pada Siswa Smp Kelas VIII. Skripsi Sarjana. Surakarta : Universitas Muhammadiyah Surakarta.

[4] Cleopatra, M. 2015. Pengaruh Gaya Hidup Dan Motivasi Belajar Terhadap Prestasi Belajar Matematika. Jurnal Formatif, 5(2)

[5] Firmansyah, D. 2015. Pengaruh Strategi Pembelajaran Dan Minat Belajar Terhadap Hasil Belajar Matematika. Jurnal Pendidikan UNSIKA, 3(1). 